\title{
THE STUDY OF THE CALENDULA FLOWERS EXTRACTION PROCESS
}

Yu.Iudina

\author{
National University of Pharmacy
}

Key words: tincture; Calendula officinalis; technology; pressure enhanced solvent extraction

This article presents the results of the study of the process of extraction of biologically active substances from the flowers of Calendula officinalis using pressure enhanced solvent extraction. The Timatic Micro laboratory extractor with the volume of 0.5 I designed for laboratory use when working with small amounts of the solvent and the product was used. The principle of its operation is based on a double action of pressure - low pressure and percolation of the plant raw material. It is possible to use various types of solvents (alcohols, water, glycerol, oils). The effect of the raw material particle size, the time of extraction, the number of cycles on quality parameters of the product has been studied. As a result of our studies, it has been found that the completeness of the BAS extraction is greatly influenced by the number of working cycles, as well as the time of the extraction process. The time of compression/decompression of the system was affected to a lesser extent. Thus, the optimal parameters of the calendula flowers extraction process are: extractant $-70 \%$ ethanol, degree of the plant raw material fineness $-3-5 \mathrm{~mm}$, the ratio of the raw material to the extractant $-1: 10$, the extraction time -5 hours, and the number of cycles -75 .

Calendula tincture is a well known drug that is in constant demand from buyers due to low prices and a wide range of the pharmacological action. Pot marigold possesses the anti-inflammatory, antibacterial, wound healing, spasmolytic, hypotensive and sedative properties, increases the metabolic function of the liver. A wide therapeutic activity of calendula is explained by the presence of a considerable number of carotenoids, flavonoids, salicylic acid, vitamins and other compounds [8-11].

At chemical and pharmaceutical enterprises Calendula tincture is obtained by simple maceration or percolation with $70^{\circ}$ ethanol $[1,3]$.

These methods of tincture production do not meet modern requirements since the time required to obtain the finished product is long enough, and the plant raw material is exhausted only by $70 \%[2,3,5,7]$.

Pressure enhanced solvent extraction takes the conventional solvent based extraction technology to a new level. This extraction technology effectively combines the use of solvents and elevated pressures to provide superior yields of high quality extracts from naturally occurring materials [4].

Extraction is carried out by the combined effect of compression/decompression and forced percolation of the solvent under pressure through the raw material layer. The extraction cycle alternates between dynamic phases obtained via a programmed pressure and static phases for transfer of the desired extract into the solvent $[4,6,12]$.

\section{Experimental Part}

Calendula flowers (Calendula officinalis $L$ ) were selected as the study subjects $[2,10]$.

The process of extraction of calendula flowers by pressurized solvent extraction (PSE) was investigated, and the technology for obtaining of calendula tincture using a 0.51 Timatic Micro extractor was developed.
The experiments on studying the effects of the particles size, the extraction time and the number of the working cycles on the yield of extractive substances were conducted.

To study the effect of the extraction time on the yield of extractives $50 \pm 0.5 \mathrm{~g}$ of the powdered calendula flowers was loaded in the extractor, filled with $70^{\circ}$ ethyl alcohol (the ratio of the raw material to the extractant was 1:10), left for 1 hour for swelling and then extracted for $60,120,180,240,300,360,420 \mathrm{~min}$. The parameters of the extraction process are shown in Tab. 1 .

While studying the effect of the number of working cycles on the yield of extractives the following parameters of extraction given in Tab. 2 were used.

After extraction the resulting extract was drained and clarified for 48 hours in the refrigerator at $8-10^{\circ} \mathrm{C}$. Then the extract was filtered, and a dry residue was obtained.

The samples obtained were tested according to the requirements specified in analytical normative documents (AND) $[2,10]$.

\section{Results and Discussion}

The completeness and speed of extraction of the active ingredients from the plant raw material depend on technological properties of the material, difference in concentrations, the time of extraction, the nature of the extractant and other factors, which should be considered in the extraction process.

The particle size affects the extraction process because it determines the phase interface between the material and the extractant. The effect of the degree of the raw material fineness on extraction of Calendula flowers was studied (Fig.).

The results showed that the most complete yield of extractive substances from the raw material was for par- 
Table 1

The parameters of the extraction process

\begin{tabular}{|l|l|}
\hline Equipment & Timatic Micro, 0.5 l; Filter bag, $100 \mathrm{mcm}$ \\
\hline $\begin{array}{l}\text { The set } \\
\text { parameters }\end{array}$ & $\begin{array}{l}\text { Compression }-8 \mathrm{~min}, \\
\text { decompression }-8 \mathrm{~min}\end{array}$ \\
\hline & Temperature $-20^{\circ} \mathrm{C}$, pressure $-5 \mathrm{bar}$ \\
\hline Time of extraction & $1-6$ hours \\
\hline Calendula flowers & $\begin{array}{l}\text { Humidity }-8 \pm 0.3 \%, \text { particle size }- \\
3-5 \mathrm{~mm}, 50 \pm 0.5 \mathrm{~g} \text { each batch }\end{array}$ \\
\hline
\end{tabular}

Table 2

The parameters of the extraction process

\begin{tabular}{|c|l|}
\hline $\begin{array}{c}\text { No. of the } \\
\text { experiment }\end{array}$ & \multicolumn{1}{|c|}{ The set parameters } \\
\hline 1 & Compression $-8 \mathrm{~min}$, decompression $-5 \mathrm{~min}$ \\
\hline 2 & Compression $-5 \mathrm{~min}$, decompression $-5 \mathrm{~min}$ \\
\hline 3 & Compression $-5 \mathrm{~min}$, decompression $-2 \mathrm{~min}$ \\
\hline 4 & Compression $-2 \mathrm{~min}$, decompression $-2 \mathrm{~min}$ \\
\hline & Temperature $-20 \pm 1^{\circ} \mathrm{C}$, pressure $-5 \mathrm{bar}$ \\
\hline $\begin{array}{c}\text { Time of } \\
\text { extraction }\end{array}$ & $4-6$ hours \\
\hline $\begin{array}{c}\text { Calendula } \\
\text { flowers }\end{array}$ & $\begin{array}{l}\text { Humidity }-8 \pm 0.3 \%, \text { particle size }-3-5 \mathrm{~mm}, \\
50 \pm 0.5 \mathrm{~g} \text { each batch }\end{array}$ \\
\hline
\end{tabular}

ticles with the size of $1 \mathrm{~mm}(28.15 \pm 0.38 \%)$. However, excessive grinding leads to contamination by ballast substances and causes difficulties in the product purification. The raw material with the particle size of 3 to $5 \mathrm{~mm}$ has the value of this index with the difference in bias between $27.11 \pm 0.47 \%$ and $26.08 \pm 0.42 \%$, respectively. Based on the results of the research we believe that to use the plant raw material with the particle size of $3-5 \mathrm{~mm}$ is the most optimal.

For our further studies a small Timatic extractor from Tecnolab (Perugia, Italy) was used. For industrial extractions the firm manufactures a larger Timatic extractor $(2001)$. The advantages of these extractors are their relatively low cost and further maintenance support by the manufacturing company.

Timatic is a solid-liquid extractor used for industrial production of herbal extracts. According to the manufacturer, percolation is achieved by alternating the dynamic phase, during which a pre-set pressure is generated, followed by the static phase, so that the solvent penetrates into the plant cells and releases again. The pressure phase prevents the formation of channels, as well as partial over-saturation of the solvent. Another advantage of this equipment is that it can be used for many different liquid solvents. It is semi-automatic, easy to handle, with a well designed display, with an automatic warning system and an automatic cleaning programme.

The effect of the extraction time on the yield of extractives. Selection of the optimum extraction time is required to obtain economically profitable tinctures on an industrial scale. The experimental results of studying the extraction time impact on the yield of extractives are shown in Tab. 3.

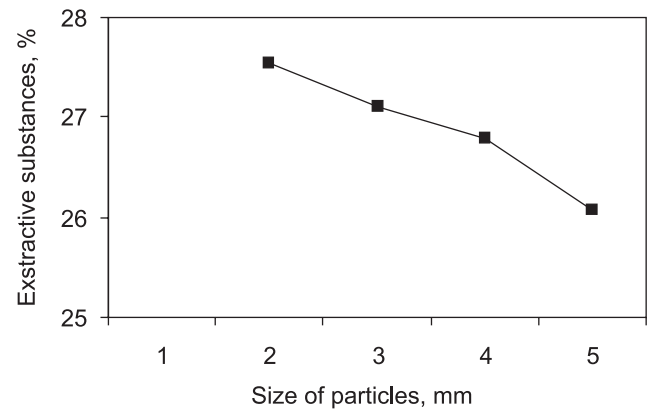

Fig. The yield of extractives of Calendula flowers depending on the size of particles.

The effect of the extraction time on the yield of extractives

\begin{tabular}{|c|c|c|}
\hline $\begin{array}{c}\text { Time of } \\
\text { extraction }\end{array}$ & $\begin{array}{c}\text { Number of } \\
\text { working cycles }\end{array}$ & Dry residue, \% \\
\hline 60 & 4 & $0.94 \pm 0.03$ \\
\hline 120 & 8 & $1.02 \pm 0.04$ \\
\hline 180 & 11 & $1.13 \pm 0.05$ \\
\hline 240 & 15 & $1.25 \pm 0.04$ \\
\hline 300 & 19 & $1.31 \pm 0.05$ \\
\hline 360 & 22 & $1.48 \pm 0.03$ \\
\hline 420 & 26 & $1.56 \pm 0.03$ \\
\hline
\end{tabular}

The extraction rate was lower than expected. According to the requirements of AND the dry residue content in the calendula tincture should be not less than 1.7\%. In the extracts obtained this parameter was in the range of $0.94-1.56 \%$, and it did not satisfy the requirements. Of the possible explanations there is a rather small number of compression-decompression working cycles. The next step of our research was to study the effect of compression-decompression cycles on the yield of a dry residue.

The effect of the number of working cycles on the yield of extractives. The process parameters, i.e. the compression time, the decompression time and the number of cycles were varied (Tab. 2). The experimental results are shown in Tab. 4.

It was noted that of all parameters the number of working cycles had the greatest impact on the extraction process, while the time of compression/decompression

Table 4

The effect of the number of working cycles on the yield of extractives

\begin{tabular}{|c|c|c|c|}
\hline \multirow{2}{*}{$\begin{array}{c}\text { Working cycle/ } \\
\text { Time of } \\
\text { extraction, } \mathrm{h}\end{array}$} & \multicolumn{3}{|c|}{$\begin{array}{c}\text { Number of working cycles / } \\
\text { Dry residue, \% }\end{array}$} \\
\cline { 2 - 4 } & 240 & 300 & 360 \\
\hline 1 & $19 /$ & $23 /$ & $27 /$ \\
& $1.29 \pm 0.04$ & $1.55 \pm 0.04$ & $1.76 \pm 0.03$ \\
\hline 2 & $24 /$ & $30 /$ & $36 /$ \\
& $1.51 \pm 0.03$ & $1.76 \pm 0.05$ & $1.95 \pm 0.03$ \\
\hline \multirow{2}{*}{3} & $35 /$ & $43 /$ & $51 /$ \\
& $1.68 \pm 0.04$ & $1.96 \pm 0.05$ & $2.17 \pm 0.04$ \\
\hline 4 & $60 /$ & $75 /$ & $90 /$ \\
& $1.88 \pm 0.05$ & $2.21 \pm 0.04$ & $2.28 \pm 0.05$ \\
\hline
\end{tabular}


Table 5

The results of determination of the calendula tincture quality indicators

\begin{tabular}{|l|c|l|}
\hline \multicolumn{1}{|c|}{ Parameter } & Calendula tincture & \multicolumn{1}{c|}{ Requirements of AND } \\
\hline Description & A yellowish-brown liquid & a yellowish-brown liquid \\
\hline Dry residue,\% & $2.21 \pm 0.05$ & not less than $1.7 \%$ \\
\hline Alcohol content,\% & $69.00 \pm 1.84$ & $\begin{array}{l}\text { the final alcohol concentration is not less than } 69 \text { per cent } \\
\text { of that of the initial extraction solvent }\end{array}$ \\
\hline Heavy metals & Corresponds & not more than $0.001 \%$ \\
\hline Thin-layer chromatography & Corresponds & according to the SPhU \\
\hline Methanol and 2-propanol & Corresponds & $\begin{array}{l}\text { maximum } 0.05 \% \text { v/v of methanol and maximum } \\
0.05 \% \text { v/v of 2-propanol }\end{array}$ \\
\hline Microbiological purity & Corresponds & not more than 1,000 bacteria and 100 fungi \\
\hline
\end{tabular}

had no significant effect. Thus, the optimal parameters of the calendula flowers extraction process have been suggested; they are: extractant $-70 \%$ ethanol, degree of the plant raw material fineness $-3-5 \mathrm{~mm}$, the ratio of the raw material to the extractant $-1: 10$, the extraction time -5 hours, and the number of cycles -75 .

Thus, with such parameters of the technological process the time extraction (compared to 48 hours in conventional percolation) significantly reduces, and the yield of extractives increases by $5 \%$

The tincture obtained was tested for compliance with the requirements of AND: description, the content of alcohol (not less than 65\%), heavy metals, dry residue (not less than $2.1 \%$ ) and microbiological purity. The results are presented in Tab. 5 .
According to the research results the indicators of quality of the product obtained meet the requirements of AND.

\section{CONCLUSIONS}

The process of extraction of biologically active substances from the flowers of Calendula officinalis using pressure enhanced solvent extraction has been studied. The effect of the raw material particle size, the time of extraction, the number of cycles on quality parameters of the product has been determined. Thus, the optimal parameters of the calendula flowers extraction process are: extractant $-70 \%$ ethanol, degree of the plant raw material fineness $-3-5 \mathrm{~mm}$, the ratio of the raw material to the extractant $-1: 10$, the extraction time -5 hours, and the number of cycles -75 .

\section{REFERENCES}

1. Вишневська Л.І., Пісковачький Ю.Г., Георгіяни В.А., Яковенко В.К. // Запорожский мед. журн. - 2007. - №4. - C. 167-170.

2. Державна фармакопея Украӥни. - 1-е вид. / Державне підприємство «Науково-експертний фармакопейний иентр». - Х.: РІРЕГ, 2001. - 556 с. Доп. 1. - 2004. - 494 с. Доп. 2. - 2008. - 620 с. Доп. 3. - 2009. - 280 с. Доп. 4. - 2011. -540 c.

3. Михайлов И.В. Современные препараты из лекарственных растений: Справочник. - М.: АСТ, 2003. $319 \mathrm{c}$.

4. Попова Н.В., Литвиненко В.И. Лекарственные растения мировой флоры. - Х.: СПДФО В.Н.Мосякин, 2008. $-510 c$.

5. Сидоров Ю.І. Екстракиія рослинної сировини. Навч. посіб. - Львів: Вид-во Нац. ун-ту «Львівська політехніка», 2008. - 336 c.

6. Chew B.P. // Anticancer Res. - 2010. - №16. - P. 3689-3694.

7. Della Loggia C.R. // Planta Med. - 1999. - №60. - P. 516-520.

8. Elias R. // Mutagenesis. - 2008. - №5 (4). - P. 327-31.

9. European Medicines Evaluation Agency. Herbal Medicinal Products Working Party Draft Core Summary of Product Characteristics for European Pharmacopoeia. - 2-nd ed. - Strasbourg: Maisonneuve, 1980.

10. European Pharmacopoeia. - 5 ed. - Strasbourg: Council of Europe, 2005. - 2416 p.

11. Jimenez-Medina E. // BMC Cancer. - 2006. - May 5-6. - P. 119.

12. Kenneth J. // The 23th ACS National Meeting. - Boston, MA. - August 19-23. - 2007. - P. 78. 


\section{ДОСЛІДЖЕННЯ ПРОЦЕСУ ЕКСТРАКЦІЇ КВІТОК КАЛЕНДУЛИ ПІД ТИСКОМ Ю.В.Юдина}

Ключові слова: Календула лікарська; настойка; технологія; екстрагування під тиском Наведені результати дослідження процесу вилучення БАР з квіток календули лікарської з використанням інтенсифрікованого методу екстракції під тиском. При роботі використовували лабораторний екстрактор Timatic Мicro об'ємом 0,5 л, призначений для лабораторного використання при роботі з невеликими кількостями розчинника і продукту. Принцип його дії грунтується на подвійному впливі тиску - зниженні тиску і перколяції рослинної сировини. Можливе використання різних типів розчинників (спиртів, води, гліцерину, олії). Було вивчено вплив розміру частинок сировини, часу екстракції, числа робочих циклів на показники якості отриманого продукту. В результаті досліджень було встановлено, що на повноту вилучення БАР більший вплив чинить кількість робочих циклів, а також час процесу екстракції. Час компресії / декомпресії системи мав незначний вплив. При цьому були встановлені оптимальні параметри ведення процесу екстракції квіток календули: екстрагент - 70\% етанол, ступінь подрібнення рослинної сировини - 3-5 мм, співвідношення сировини до екстрагенту 1:10, час екстракції - 5 годин, кількість робочих циклів - 75.

\section{ИЗУЧЕНИЕ ПРОЦЕССА ЭКСТРАКЦИИ ЦВЕТКОВ КАЛЕНДУЛЫ ПОД ДАВЛЕНИЕМ Ю.В.Юдина \\ Ключевые слова: Календула лекарственная; настойка; технология; экстракция под давлением}

Приведены результаты исследования прочесса извлечения БАВ из цветков календулы лекарственной с использованием интенсифицированного метода экстракции под давлением. Был использован лабораторный экстрактор Timatic Micro объемом 0,5 л, предназначенный для лабораторного использования при работе с небольшими количествами растворителя и продукта. Принцип его действия основан на двойном воздействии давления - понижении давления и перколяции растительного сырья. Возможно использование различных типов растворителей (спиртов, воды, глицерина, масла). Было изучено влияние размера частиц сырья, времени экстракции, числа рабочих циклов на показатели качества полученного продукта. В результате исследований было установлено, что на полноту извлечения БАВ большее влияние оказывает количество рабочих циклов, а также время процесса экстракции. Время компрессии/декомпрессии системы оказывало незначительное влияние. При этом были установлены оптимальные параметры ведения процесса экстракции цветков календулы: экстрагент - 70\% этанол, степень измельчения растительного сырья - 3-5 мм, соотношение сырья к экстрагенту 1:10, время экстракции - 5 часов, количество рабочих циклов - 75. 